\title{
Application of Matrix Approach for Evaluation and Assessment the Potential of Recreational Ecosystem Service in Model Regions in Slovakia
}

\author{
Jarmila Makovníková ${ }^{*}{ }^{\circledR}$, Boris Pálka1 ${ }^{10}$, Stanislav Kolosta ${ }^{2}$ (D) Katarína Orságová $^{2}$ \\ ${ }^{1}$ National Agricultural and Food Centre/Soil Science and Conservation Research Institute, Bratislava, Slovakia \\ ${ }^{2}$ Matej Bel University in Banská Bystrica, Faculty of Ecomonics, Banská Bystrica, Slovakia \\ Email: ^jarmila.makovnikova@nppc.sk
}

How to cite this paper: Makovníková, J., Pálka, B., Kolosta, S. and Orságová, K. (2021) Application of Matrix Approach for Evaluation and Assessment the Potential of Recreational Ecosystem Service in Model Regions in Slovakia. Open Journal of Ecology, 11, 437-450.

https://doi.org/10.4236/oje.2021.114028

Received: March 18, 2021

Accepted: April 24, 2021

Published: April 27, 2021

Copyright $\odot 2021$ by author(s) and Scientific Research Publishing Inc. This work is licensed under the Creative Commons Attribution International License (CC BY 4.0).

http://creativecommons.org/licenses/by/4.0/

cc) (i) Open Access

\begin{abstract}
Recreation and tourism are important for economic growth and human wellbeing. They are directly related to the cultural services provided by ecosystems. Recreational services, as part of tourism, have the greatest potential for development within the sector of services in the Slovak economy, and they are able to generate a significant number of new jobs especially in small rural regions. There is a gap in the literature providing assessments of geographically small regions in relation to their potential to provide different types of ecosystem services. The aim of the article was to evaluate and assess the recreational potential of ecosystem services in two small pilot regions of the Slovak Republic, Brezno district and Krupina district. Modified matrix of indices was used. Results showed that Brezno district has a higher area of ecosystems with a higher potential for recreation, therefore the conditions for recreation and tourism are much better in comparison to Krupina district. However, the use of recreation potential in Brezno district is negatively affected by the availability of sites and transport options, which is reflected in a lower ratio of visitors to the capacity of recreation potential. This finding opens up discussion about opportunities to create new jobs within sustainable tourism in Brezno district. This study provides an alternative view to the assessment and evaluation of the recreational potential of ecosystem services in small regions. Moreover, the methodology developed in this paper is replicable and could be applied by planners using geographical information systems.
\end{abstract}

\section{Keywords}

Potential, Ecosystem Services, Recreational Services, Evaluation, Assessment 


\section{Introduction}

Interconnections of the economy with ecological dimensions are clearly visible through the services provided by ecosystems, which are referred as natural capital [1]. The concept of ecosystem services represents a bridge between ecological and economic approaches and helps to create a transdisciplinary ecological economy, where the provision of recreational services within the service sector as the fastest growing sector of the world economy [2] is challenging for sustainable land management. One of the main requirements for the implementation of the concept of ecosystem services into institutional decision-making is the explicit evaluation and assessment of ecosystem services. The system approach assumes the estimation of the values and services of the ecosystem they provide, including causal mechanisms within ecological systems [3] [4]. Ecosystem services linked to natural capital are divided by Dominati et al. [5] into three basic groups: provisioning, regulating, and cultural ecosystem services. Biodiversity is not classified as an ecosystem service, but it is a basic prerequisite for their healthy functioning. Cultural ecosystem services are defined in the Millennium Assessment of Ecosystem Services [6] as the intangible benefits that people derive from ecosystems through spiritual enrichment, cognition, recreation, aesthetic, and other experiences. The analysis and assessment of cultural services are also important for the management of ecosystems (including agroecosystems), where arable land has the potential to provide cultural ecosystem services, but grasslands dispose of real prerequisites for their fulfillment, especially those focused on recreation [7] [8].

Recreation and tourism are important parts of the economy; they also contribute to the improvement of quality of life [9], overall well-being, and education. Based on a survey, Martín-López et al. [10] found that more than $40 \%$ of respondents identified nature tourism as one of the most important ecosystem services. In the future, the share of natural tourism on gross domestic product is expected to increase [11] [12]. The availability of recreational services and their use depends on built infrastructure, natural potential of the area [13], attractiveness of the landscape, diversity of habitats, occurrence of protected areas and water areas. Many farmers analyze the possibilities of using agricultural land not only for production but also for agrotourism and ecotourism [14]. Page and Dowling [15] consider natural (eco)tourism as a sustainable form of tourism based on natural welfare, primarily focused on experiences and study, ethically driven towards low impact on nature, zero consumption of natural welfare, and with regional focus. Wiezik et al. [16] mention the possibility of using ecosystem services as a modern tool in the management of protected areas in connection with the development of nature tourism in Slovakia. There is a gap in the literature providing assessments of geographically small regions in relation to their potential to provide different types of ecosystem services. The aim of the article was to evaluate and assess the recreational potential of ecosystem services in two small pilot regions of the Slovak Republic. 


\section{Materials and Methods}

\subsection{Data}

CORINE Land Cover (CLC) data from year 2016 and LPIS data (Land Parcel Identification System) were used as basis for the valuation approach. These data were interpreted and converted into 9 land cover classes. For data analysis and output processing we used ESRI's software package ArcGIS for Desktop Advanced version 10.3. regular network (grid) with a size of $100 \times 100$ meters was used as the basic spatial unit for presentation of geographical data.

\subsection{Study Area}

We chose two small model regions of Central Slovakia, Krupina and Brezno districts (LAU 1 regional level according to administrative territorial classification of Slovakia), to evaluate potential of recreational ecosystem services. Model sites are located in various natural and climatic conditions, e.g. different forest coverage and spatial protection areas NATURA 2000, different environmental quality and land use.

\section{Krupina district}

The location is in the south of central Slovakia (Figure 1) with an area of 548 $\mathrm{km}^{2}$. According to the currently valid Regionalization of Tourism in the Slovak Republic [17], Krupina district belongs to the Ipel tourism region and belongs to regions with satisfactory quality of environment. It is rugged in height with $96 \%$ of the territory up to 600 meters above sea level, of which $60 \%$ is from 300 to 600 meters above sea level; $26 \%$ of the area on the plain and half of the area with a slight slope. The climate varies mostly from very warm (58.9\%) to moderately warm (36.6\%). Recreational potential is currently mostly focused on sightseeing (e.g. ruins of castles-Sitno, Čabrad, Pustý hrad, Bzovík) supplemented to a lesser extent by nature tourism with predominance of one-day visits (most favorite nature locations are Štiavnické vrchy, Gavurky, Mäsiarsky bok, Čertova skala, Bralce or Tesárska roklina; rafting on the river Ipel). Due to warm climate, the potential for winter activities is very low.

\section{Brezno district}

The location is in the middle of central Slovakia (Figure 1). With an area of $1265 \mathrm{~km}^{2}$ is the sixth largest district in Slovakia. According to the currently valid Regionalization of Tourism in the Slovak Republic [17], Brezno district is part of the Horehronie tourism region and belongs to regions with high quality of environment. The majority of the district is located at an altitude of over 600 meters above sea level (88.6\%) with the lowest point at 406 meters above sea level. This is related to the predominance of cold climate ( $86.9 \%$ of the area). Recreational potential is currently most often used for one-day nature tourism including mountain biking, hiking, climbing, caving and winter sports by locals as well as residents outside the district. The exception is area around Chopok peak in Low Tatras National Park where recreation services are well developed during whole year (e.g. sport activities, wellness, folk activities or nature tourism). 


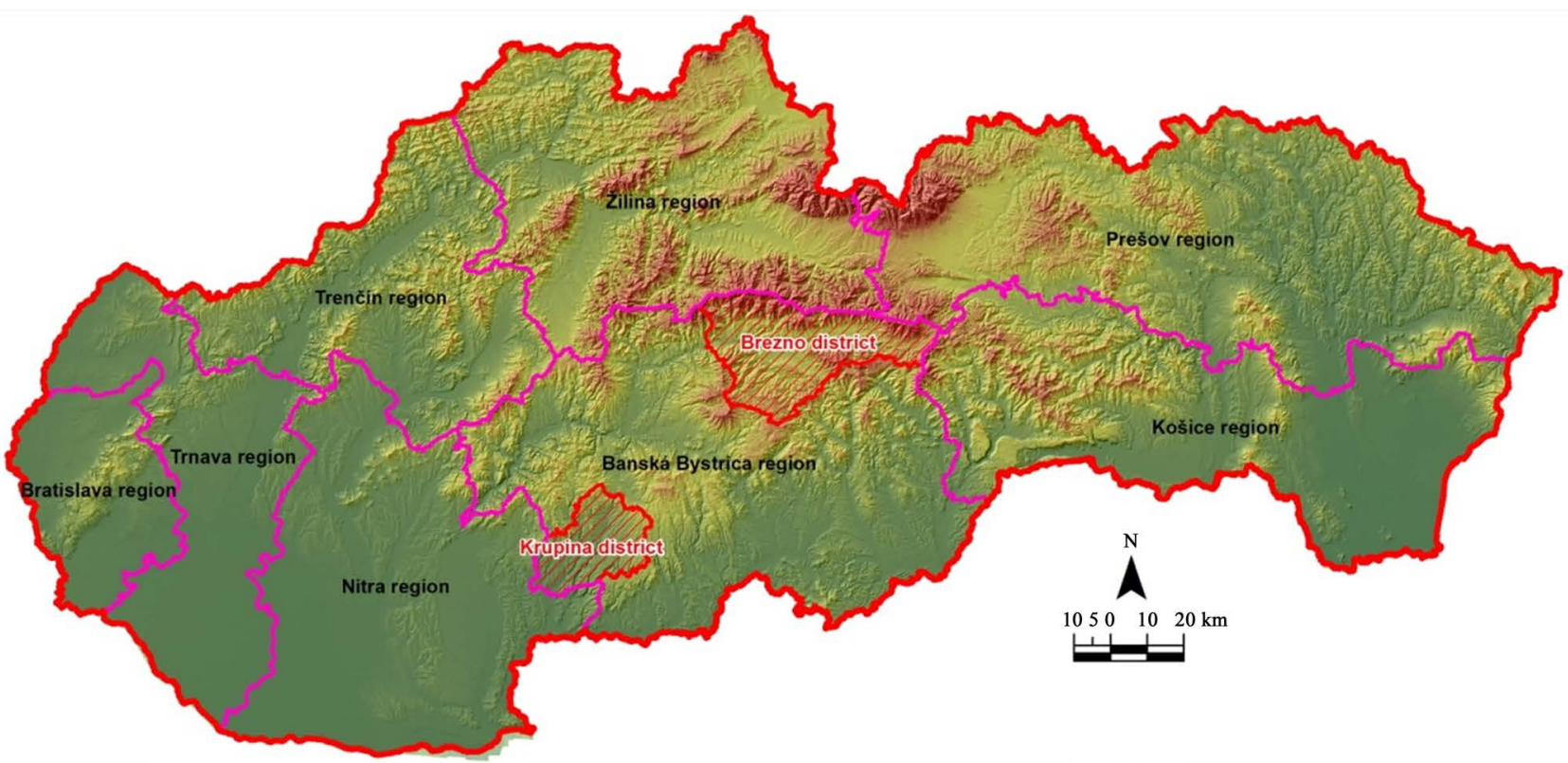

Source: Own processing.

Figure 1. Localization of study area on the map of Slovakia.

\subsection{Methodology}

We used Burkhard matrix [18] according to Černecký [19] modification to evaluate and assess the potential of recreation ecosystem services which belongs to the group of cultural services provided by ecosystems. Assessment the potential of ecosystem services by index matrix using an expert scoring system belongs to the most frequently used methods [20]. To each ecosystem was assigned an index value ranging from 0 to 5 according to its potential. Ecosystems that do not produce a significant amount of ecosystem service had 0 value. Land cover classes arable land and grassland were divided into three land cover subclasses based on results of project "Modeling and Evaluation of Agroecosystem Services" [21] where the model RegMod was used [22]. The matrix was modified for the purposes of recreation evaluation in the model sites as follow. The RegMod model was based on the analysis of the suitability of natural conditions for summer, winter, and year-round recreation and was supplemented by the territorial quantification of NATURA 2000, increasing the attractiveness of the assessed areas. Potential of recreation ecosystem services was assessed by the analysis of natural preconditions for the implementation of recreation (rating criteria) and assessment of biophysical parameters [22]. The RegMod model assessed the potential of recreation services in 5 categories, from very low to very high. Based on RegMod results, the area of agricultural land (arable land and permanent grassland) for the model sites was divided into three categories: 1) category was computed as the sum of the area of very low and low recreation potential (the index value was reduced by $1 / 3$ compared to the mean value), 2) category was the mean potential (corresponds to the mean value of the index), and 3) category was the area of high and very high recreation potential in the model sites (the value of 
the index was increased by $1 / 3$ compared to the mean value). The determination of the average recreation potential index $\left(I_{R}\right)$ for the model sites was as follows:

$$
I_{R}=\left(\sum I_{R e} \cdot P_{e}\right) / P \text {, }
$$

where $I_{R}$ was the average recreation potential index, $I_{R e}$ was the recreation potential index of a particular ecosystem, $P_{e}$ was the area of a particular ecosystem in a model site, and $P$ was the total area of ecosystems in the model site.

We used the Value transfer method [23] to determine the value of the recreation potential. The evaluation of the recreation potential was based on the study by [19] [24]. For the index value, $I_{R}=1$ was assigned the monetary value 730.1733 EURO [24]; the prices of recreational services for individual ecosystems were subsequently calculated according to the index matrix. The evaluation of the recreation potential $(\mathrm{CR})$ for the model sites was as follows:

$$
C R=\sum C_{R e} \cdot P_{e},
$$

where $C R$ was the total value of the recreation potential, $C_{R e}$ was the value of the recreation potential of a particular ecosystem, $P_{e}$ was the area of a particular ecosystem in a model site. The assessment and mapping methodology developed in this paper is replicable and could be applied by planners using geographical information systems at different levels, from small regional (district) to national level.

\section{Results and Discussion}

Table 1, Figure 2 and Figure 3 contain the area of ecosystems determined using the CLC and LPIS databases in Krupina and Brezno districts.

Cultural ecosystem services are seldom reflected by economic indicators and therefore are rarely marketable [12] [24]. The values of the recreation potential indices of individual ecosystems (index matrix was modified according to Burkhard

Table 1. Area of ecosystems in Krupina and Brezno districts in hectares (ha).

\begin{tabular}{ccc}
\hline Land cover class/Ecosystem & Krupina district & Brezno district \\
\cline { 2 - 3 } Arable land & $15,266.6$ & 3221.7 \\
Grassland & 9362.1 & $17,455.6$ \\
Vineyards & 73.2 & 0.0 \\
Fruit trees and berries & 30.5 & 0.5 \\
Agro-forestry areas-fast growing woody plants & 163.7 & 0.0 \\
Water bodies & 60.1 & 20.2 \\
Wetlands & 0.3 & 3.2 \\
Natural protected areas & 1109.0 & $38,745.8$ \\
Forest & 6653.6 & $30,406.3$
\end{tabular}

Source: Own processing using the CLC database and the LPIS database. 


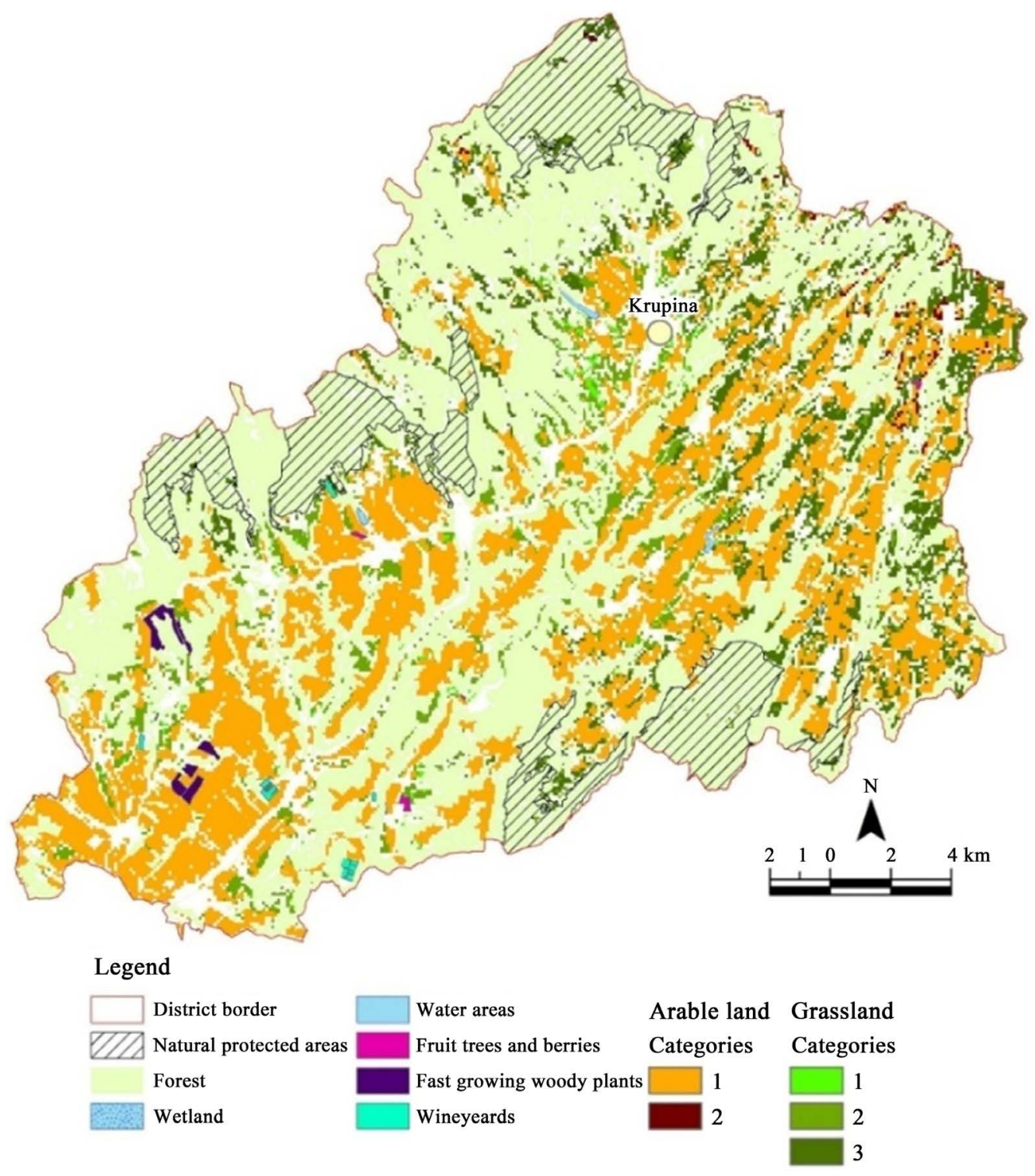

Source: Own processing.

Figure 2. Types of ecosystems on the map of Krupina district.

et al. [18]; Černecký et al. [19]) supplemented by the values of recreation potential of individual ecosystems in EURO per hectare are presented in Table 2 and Figure 4. Protected areas (national parks), forest ecosystems, wetlands of national importance, and water areas have the highest potential of recreation ecosystem services in model sites.

Agroecosystems have a lower potential for providing cultural ecosystem services, particularly recreational activities linked to natural resources such as hiking, biking, cross-country skiing, etc., in comparison to other types of ecosystems [25]. According to Burkhard et al. [26] agricultural use of grassland has predominantly medium potential to provide recreational services (outdoor activities). Grasslands contribute significantly to ecotourism that generates many economic benefits for local communities related to farming [14]. The capacity of 
ecosystems to provide recreational service depends on the particular uniqueness of the ecosystem, its accessibility, and the surrounding infrastructure [21] [22]. The estimated value including $\%$ share of individual ecosystems on the total

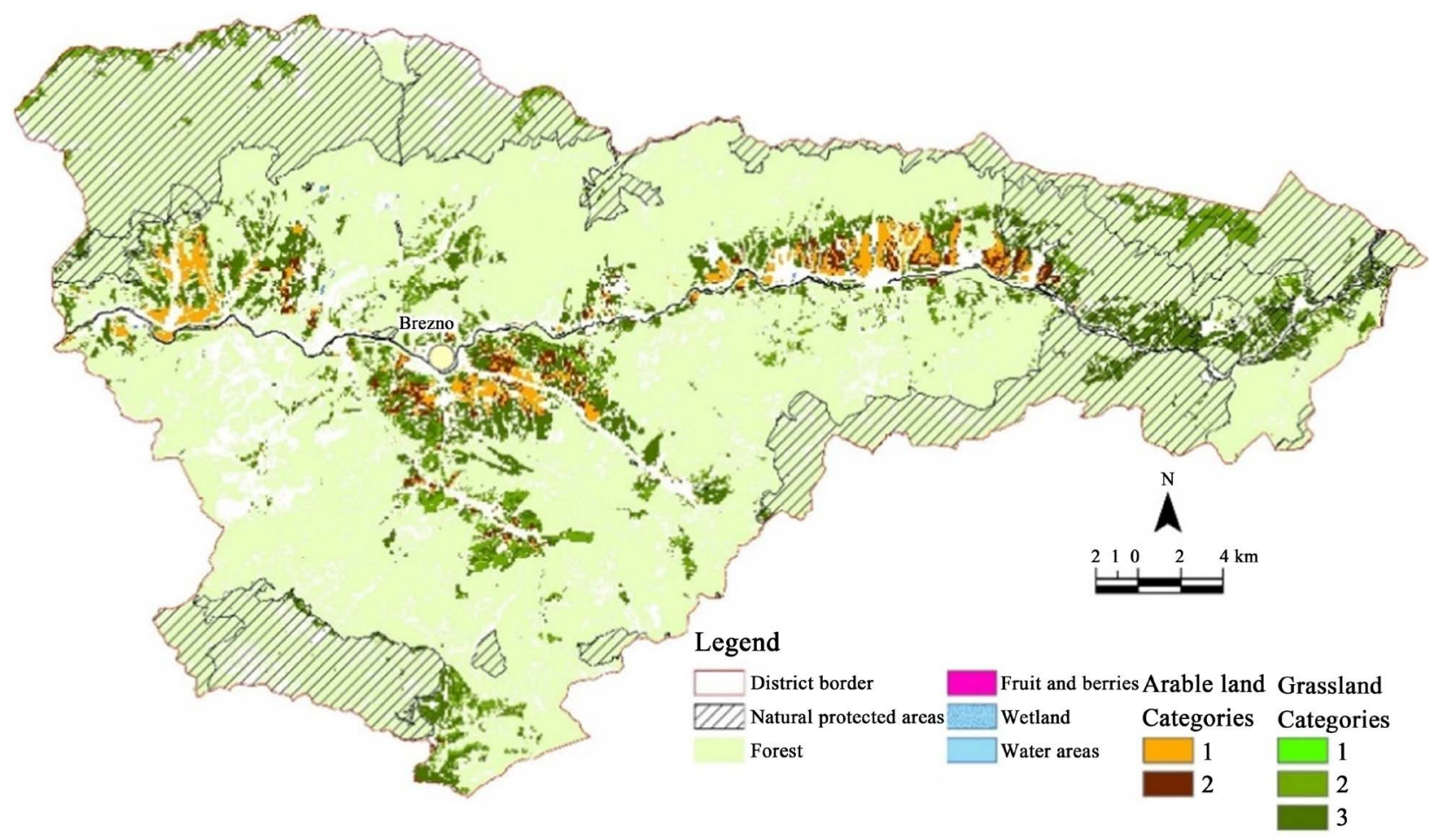

Source: Own processing.

Figure 3. Types of ecosystems on the map of Brezno district.

Table 2. The capacity of ecosystems to provide recreational services-modified potential matrix.

\begin{tabular}{cccc}
\hline \multirow{2}{*}{\begin{tabular}{c} 
Land cover class/ecosystem \\
\multirow{2}{*}{ Arable land }
\end{tabular}} & Land cover subclass & $\begin{array}{c}\text { Index of recreational } \\
\left.\text { potential ( } \mathrm{I}_{\mathrm{R}}\right)\end{array}$ & $\begin{array}{c}\text { Value in } € \text { Euro } \\
\text { per hectare (ha) }\end{array}$ \\
& Arable land-category 1 & 0.7 & 511.1213 \\
& Arable land-category 2 & 1 & 730.1733 \\
& Arable land-category 3 & 1.3 & 949.2253 \\
Grassland & Grassland-category 1 & 1.4 & 1022.243 \\
& Grassland-category 2 & 2 & 1460.347 \\
Vineyards & Grassland-category 3 & 2.6 & 1898.451 \\
Fruit trees and berries & & 1.07 & 781.2854 \\
Waro-forestry areas-fast growing woody plants & & 1.07 & 781.2854 \\
Water bodies & & 1 & 730.1733 \\
Wetlands & & 3.63 & 2650.529 \\
Natural protected areas & & 5 & 3650.867 \\
Forest & 5 & 3650.867 \\
\hline
\end{tabular}

Source: Own calculations using input parameters from Burkhard et al. (2014), Černecký et al. (2020). 
Table 3. Recreational potential—estimated value of individual ecosystems in Krupina and Brezno district in $€$ Euro currency (including \% share on total value of recreational potential of ecosystem services of district).

\begin{tabular}{cccc}
\hline \multirow{2}{*}{ Land cover class/ecosystem } & Land cover subclass & Krupina district & Brezno district \\
\cline { 3 - 4 } & & \multicolumn{2}{c}{$€$} \\
\hline \multirow{2}{*}{ Arable land } & Arable land-category 1 & $4,025,611.34(7.791 \%)$ & $200,565.56(0.071 \%)$ \\
& Arable land-category 2 & $2,339,810.65(4.528 \%)$ & $879,091.62(0.310 \%)$ \\
& Arable land-category 3 & $3,973,553.62(7.690 \%)$ & $1,542,821.09(0.544 \%)$ \\
Grassland & Grassland-category 1 & $4,937,337.18(9.555 \%)$ & $2,173,381.93(0.767 \%)$ \\
Vineyards & Grassland-category 2 & $2,869,734.10(5.554 \%)$ & $9,526,071.19(3.362 \%)$ \\
Fruit trees and berries & Grassland-category 3 & $4,873,489.36(9.432 \%)$ & $16,718,420.64(5.900 \%)$ \\
Agro-forestry areas- & & $57,190.09(0.111 \%)$ & $0.000(0.000 \%)$ \\
fast growing woody plants & & $23,829.21(0.046 \%)$ & $390.64(0.0001 \%)$ \\
Waterbodies & & $119,529.37(0.231 \%)$ & $0.00(0.000 \%)$ \\
Wetlands & & $159,296.80(0.308 \%)$ & $53,540.68(0.019 \%)$ \\
Protected areas CHVU & & $1095.26(0.002 \%)$ & $11,682.77(0.004 \%)$ \\
Forest & $4,048,811.5(7.836 \%)$ & $141,455,743.20(49.923 \%)$ \\
\hline & & $24,242,822.53(46.917 \%)$ & $110,787,323.4(39.099 \%)$ \\
\hline
\end{tabular}

Source: Own processing.

value of the recreation potential of cultural ecosystem services in the Krupina and Brezno district is shown in Table 3.

The average value of the potential of recreational service index in Slovakia was estimated for 3.13 [19]. The Brezno district has a significantly higher value of the recreation potential index (4.32) than the average value for Slovak Republic due to the high representation of national parks (NATURA 2000 areas), protected areas, and forest ecosystems (part of the Muránska planina National Park, the Low Tatras National Park, the Slovak Paradise National Park, and the Polana National Park; Figure 4).

Považan et al. [27] estimated the total value of Muránska planina national park to 5,024,718 Euro per year. Our estimation of the potential of recreational ecosystem services value for the whole Brezno district was 283,349,032.8 EURO. Krupina district is characterized by a high share of agricultural land (mainly arable land) and our results showed that it has a relatively low recreational potential index (2.06) compared to Brezno district as well as to Slovak average (the most attractive for recreation is the protected area Štiavnicke vrchy). Wetland habitats represent attractive localities for recreation and tourism, but their area within Krupina district is very low ( $0.32 \mathrm{ha})$. Higher potential for recreation and tourism is reflected in the higher number of catering and accommodation establishments in Brezno district (in the year 2018 it was 61 in Brezno district in comparison to 26 in Krupina district; data of Slovak statistical office). Figure 5 


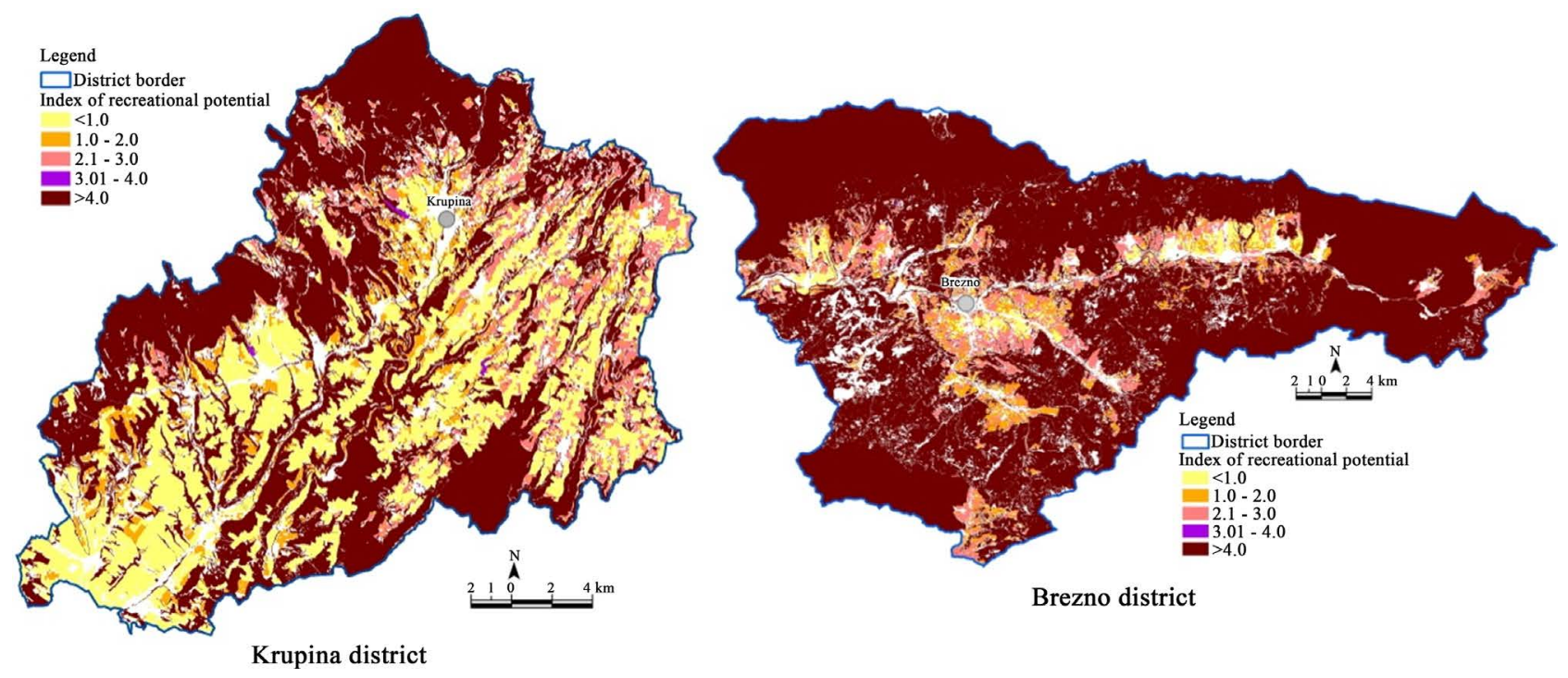

Figure 4. Index of recreational potential $\left(\mathrm{I}_{\mathrm{R}}\right)$ on the map of Krupina district and Brezno district.

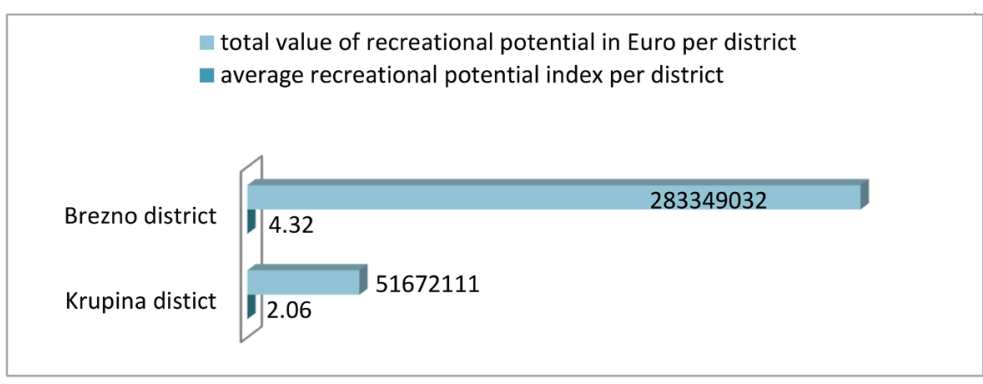

Source: Own processing.

Figure 5. Values of recreational potential indices $I_{R}$ (numerical) and its monetary evaluation (in Euro).

illustrates the value of recreational potential indices and its monetary evaluation for both districts.

The usage of natural capital for recreation is influenced not only by natural, but also by the economic and demographic conditions of the model sites. In Brezno district, there are the demographic conditions for recreation and tourism better than in Krupina district; however both districts suffered a decrease in the total number of inhabitants in past 10 years (Brezno district $-4.2 \%$, Krupina district $-2.1 \%)$. These are not positive tendencies especially for Brezno district with very high potential for recreation and tourism within which domestic inhabitants should be involved. For example, in England 23\% of farmers are also active in agrotourism, and in France hikers and cyclists can follow a network of trails around the country that leads from farm to farm [14].

According to Milcu et al. [12] the accessibility is a crucial factor that effects the use of recreational services which is also reflected in the ratio of the total number of visitors to the capacity of the recreation potential; this ratio was lower for Brezno district $\left(1.94107 \mathrm{E}^{-07}\right)$ in comparison to Krupina district $\left(3.4835 \mathrm{E}^{-07}\right)$; illustration provides Figure 6. People must be able to reach recreation sites in 


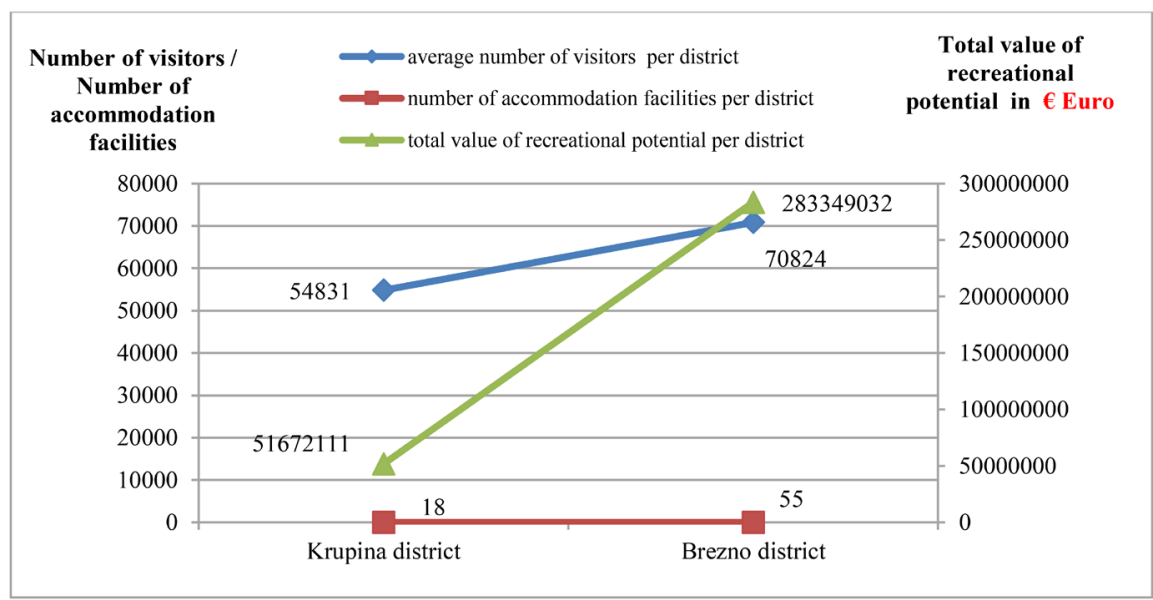

Source: Own processing.

Figure 6. Comparison of the value of recreation potential with the average number of visitors and the number of accommodation establishments in model sites (average for the last 10 years).

order to ecosystem service flow, therefore the accessibility is essential [7]. The accessibility of the Krupina district could be improved by the planned construction of the R3 expressway with a continuation to the Šahy-Parassapuszta Hungarian border crossing, and for Brezno district is crucial the completion of the R1 expressway including the completion of the Brezno city bypass.

According to the Millennium Ecosystem Assessment Report [28], the use of ecosystem potential for recreation and tourism is growing due to the increased population, greater leisure opportunities as well as infrastructure development. In Brezno district, there is more room for effective sustainable usage of recreational potential of cultural ecosystem services compared to Krupina district. This poses a challenge for the sustainable management of territorial development at regional and local level.

\section{Conclusions}

The usage of the potential of natural capital for recreation is influenced by the natural, economic and demographic conditions of the model sites. In Brezno district, where the area of ecosystems with a high potential for recreation is higher, the conditions for recreation and tourism are more advantageous in comparison with Krupina district. However, the use of recreation potential in Brezno district is negatively affected by the availability of sites and transport options together with insufficient cooperation of stakeholders and lower level of tourism services [29], which is reflected in a lower ratio of visitors to the capacity of recreation potential. Almost the same reasons can be found in Krupina district [30] where, in addition, unoccupied accommodation capacity and poor state of cultural monuments can be found. This opens up a discussion about opportunities to create new jobs focused on recreation and tourism with emphasis on their sustainable nature. When assessing ecosystem services, the relationship between the quality and quantity of ecosystem services is determined by the health of the eco- 
systems. Maes [31] demonstrated a clear relationship between habitat status and the provision of ecosystem services and stated that non-degraded habitats have a higher ability to provide ecosystem services in higher quality and quantity. This was also the case of Brezno district with well-preserved habitats (high share of protected areas and forests) in comparison to Krupina district where land is used mainly for intensive agriculture.

Recreational activities affect the environment, ecosystems, and, consequently the services they provide. Qualified area modifications that allow access of tourism participants to a certain area have a positive effect (e.g., access to caves, alpine trails, construction of ski slopes; [32]). Benefits can be taken also from financial investments to the construction of suitable infrastructure or compensatory measures to mitigate the negative effects of human activities on habitats. Recreation potential of ecosystems is negatively affected by the consumption of natural resources, waste production, the increase in tourist traffic, and intensity usage of available tourist infrastructure [32]. An important factor of successful sustainable use of the recreational potential of ecosystem services is building the trust between local entrepreneurs, landowners, and local governments in relation to the qualitative change in economic growth parameters because recreational services are the most promising area of service sector in Slovakia [33]. This study provides an alternative view to the assessment and evaluation of the recreational potential of ecosystem services in small regions in Slovakia. In the near future, we can expect rising interest in the assessment and evaluation of the recreational potential of ecosystem services in regions of the Slovak Republic due to the EU's ambitions focusing on a circular economy.

\section{Acknowledgements}

This publication was supported by the Operational program Integrated Infrastructure within the project: Sustainable smart farming systems taking into account the future challenges 313011 W112, co-financed by the European Regional Development Fund and the Slovak Research and Development via contract No. APVV-18-0035 "Valuing ecosystem services of natural capital as a tool for assessing the socio-economic potential of the area".

\section{Conflicts of Interest}

The authors declare no conflicts of interest regarding the publication of this paper.

\section{References}

[1] Costanza, R. and Daly, H.E. (1992) Natural Capital and Sustainable Development. Conservation Biology, 6, 37-463. https://doi.org/10.1046/j.1523-1739.1992.610037.x

[2] World Trade Organization (2019) World Trade Report. World Trade Organization, Geneva,19 p.

[3] Boumans, R., Costanza, R., Farley, J., Wilson, M.A., Portela, R., Rotmans, J., Villa, F. and Grasso, M. (2002) Modeling the Dynamics of the Integrated Earthsystem and 
the Value of Global Ecosystem Services Using the GUMBO Model. Ecological Economics, 41, 529-560. https://doi.org/10.1016/S0921-8009(02)00098-8

[4] Braat, L.C. and de Groot, R. (2012) The Ecosystem Services Agenda: Bridging Theworlds of Natural Science and Economics, Conservation and Development, and Public and Private Policy. Ecosystem Services, 1, 4-15.

https://doi.org/10.1016/j.ecoser.2012.07.011

[5] Dominati, E., Patterson, M. and Mackay, A. (2010) A Framework for Classifying and Quantifying the Natural Capital and Ecosystem Services of Soils. Ecological Economics, 69, 1858-1868. https://doi.org/10.1016/j.ecolecon.2010.05.002

[6] MEA (Millennium Ecosystem Assessment) (2005) Ecosystems and Human WellBeing: Our Human Planet: Summary for Decision Makers. Vol. 5, Island Press, Washington DC.

[7] Paracchini, M.L., Zulian, G., Kopperoinen, L., Maes, J., Schägner, J.P., Termansen, M., Zandersen, M., Perez-Soba, M., Scholefield, P.A. and Bidoglio G. (2014) Mapping Cultural Ecosystemservices: A Framework to Assess the Potential for Outdoor Recreation Acrossthe EU. Ecological Indicators, 45, 371-385.

https://doi.org/10.1016/j.ecolind.2014.04.018

[8] Joyce, K. and Sutton, S. (2009) A Method for Automatic Generation of the Recreation Opportunity Spectrum in New Zealand. Applied Geography 29, 409-418. https://doi.org/10.1016/j.apgeog.2008.11.006

[9] Bratman, G.N, Anderson, C.B, Berman, M.G., Cochran, B., de Vries, S., et al. (2019) Nature and Mental Health: An Ecosystem Service Perspective. Science Advances, 5, eaax0903. https://doi.org/10.1126/sciadv.aax0903

[10] Martín-López, B., Iniesta-Arandia, I., García-Llorente, M.,Palomo, I., Casado-Arzuaga, I., García Del Amo, D., et al. (2012) Uncovering Ecosystem Services Bundles Throughs Ocialp References. PLOS ONE, 7, e38970. https://doi.org/10.1371/journal.pone.0038970

[11] Mehmetoglu, M. (2007) Typologi Singnature-Based Tourists by Activity-Theoretical and Practical Implications. Tourism Management, 28, 651-660.

https://doi.org/10.1016/j.tourman.2006.02.006

[12] Milcu, A., Hanspach, J., Abson, D. and Fischer, J. (2013) Cultural Ecosystem Services: A Literature Review and Prospects for Future Research. Ecology and Society, 18, Article No. 44. https://doi.org/10.5751/ES-05790-180344

[13] Maes, J., Braat, L., Jax, K., Hutchins, M., Furman, E., Termansen, M., et al. (2011) A Spatial Assessment of Ecosystem Services in Europe: Methods, Case Studies and Policy Analysis-Phase 1. PEER Report No. 3, Partnership for European Environmental Research, Ispra.

https://www.ufz.de/export/data/2/99145_Maes_et_al._2011_A_spatial_assessment_ of_ecosy.pdf

[14] Parente, G. and Bovolenta, S. (2012) The Role of Grassland in Rural Tourism and Recreation in Europe. In: Parente, G. and Bovolenta, S., Eds., Grassland-A European Resource? Grassland Science in Europe, Vol. 17, Polish Grassland Society, 733-743.

[15] Page, J.S. and Dowling, R.K. (2002) Ecotourism: Theme in Tourism. Pearson Education, Essex.

[16] Wiezik, M., Niňajová, I., Švajda, J. and Elexová, L. (2019) The Concept of Nature Tourism in Slovak Conditions (Koncept prírodného turizmu v slovenských podmienkach). Aevisn.o. $39 \mathrm{~s}$

[17] Weiss, P., et al. (2005) Regionalization of Tourism in the Slovak Republic (Regionalizácia cestovného ruchu v Slovenskej republike). Ministerstvo hospodárstva SR, 
Bratislava, $114 \mathrm{~s}$.

[18] Burkhard, B., Kandziorai, M.S. and Müller, F. (2014) Ecosystem Service Potentials, Flows and Demands-Concepts for Spatial Localisation, Indication and Quantification. Landscape Online, 34, 1-32. https://doi.org/10.3097/LO.201434 http://www.landscapeonline.de/103097lo201434

[19] Černecký, J., Gajdo, P., Ďuricov, V., Černeck,á L., Švajda, J., Andráš, P., Ulrych, L., Rybanič, R. and Považan, R. (2020) The Value of Ecosystems and Their Services in Slovakia (Hodnota ekosystémov a ich služieb na Slovensku). ŠOP SR, Banská Bystrica, $166 \mathrm{p}$.

[20] Campagne, C. and Roche, P. (2018) May the Matrix Be with You! Guidelines for the Application of Expert Based Matrix Approach for Ecosystem Services Assessment and Mapping. One Ecosystem, 3, e24134. https://doi.org/10.3897/oneeco.3.e24134

[21] Makovníková, J., Pálka, B., Siráň, M., Kanianska, R., Kizeková, M. and Jadudová, J. (2017) Modeling and Assessing of Agroecosystem Services (Modelovanie a hodnotenie agroekosystémových služieb). Belianum, Banská Bystrica.

[22] Makovníková, J., Kobza, J., Pálka, B., Mališ, J., Kanianska, R. and Kizeková, M. (2016) An Approach to Mapping the Potential of Cultural Agroecosystem Services. Soil and Water Research, 11, 44-52. https://doi.org/10.17221/109/2015-SWR

[23] Burkhard, B. and Maes, J. (2017) Mapping Ecosystem Services. Advanced Books, Pensoft Publishers, Sofia. https://doi.org/10.3897/ab.e12837

[24] Frélichová, J., Vačkář, D., Pártl, A., Loučková, B., Harmáčková, Z. and Lorencová, E. (2014) Integrated Assessment of Ecosystem Services in the Czech Republic. Ecosystem Services, 8, 110-117. https://doi.org/10.1016/j.ecoser.2014.03.001

[25] Makovníková, J., Pálka, B., Širáň, M., Kanianska, R. and Kizeková, M. (2017) Potential of Agroecosystem Services. The Case of Slovakia. Agricultural Research \& Technology: Open Access Journal, 8, Article ID: 555727.

[26] Burkhard, B., Kroll, F., Müller, F. and Windhorst, W. (2009) Landscapes' Capacities to Provide Ecosystem Services-A Concept for Land-Cover Based Assessments. Landscape Online, 15, 1-22. https://doi.org/10.3097/LO.200915

[27] Považan, R., Getzner, M. and Švajda, J. (2015) On the Valuation of Ecosystem Services in Muránska Planina National Park (In Slovak). Journal on Protected Mountain Areas Research and Management, 7, 61-69. https://doi.org/10.1553/eco.mont-7-2s61

[28] Reid, W.V., Mooney, H.A., Cropper, R.A., Capistrano, D., Carpenter, S.R., Chopra, K., et al. (2005) Millenium Ecosystem Assessment (Ekosystémy a lidský blahobyt). Praha: World Resource Institute, Centrum pro otázky životního prostředí. Univerzita Karlova v Prahe, 138 p.

[29] Program hospodárskeho a sociálneho rozvoja mesta Brezno (2008) Program of Economic and Social Development of the City of Brezno.

https://app.otvorenestrategie.sk/dokument/1929

[30] Program hospodárskeho a sociálneho rozvoja mesta Krupina (2016) Program of Economic and Social Development of the City of Krupina. https://app.otvorenestrategie.sk/repozitar/prehlad?visualPaginator_Dokumenty-pag $\underline{\mathrm{e}=64}$

[31] Maes, J, Paracchini, M.L, Zulian, G., Dunbar, M.B. and Alkemade, R. (2012) Synergies and Trade-Offs between Ecosystem Service Supply, Biodiversity, and Habitat Conservation Status in Europe. Biological Conservation, 155, 1-12. https://doi.org/10.1016/j.biocon.2012.06.016

[32] Kanianska, R., Jad’udová, J., Makovníková, J., Kizeková, M. and Tomaškin, J. (2016) 
Ecosystem Services (Ekosystémové služby). Belianum. Vydavatelstvo Univerzity Mateja Bela v Banskej Bystrici, 244 s.

[33] Ministry of Economy of the Slovak Republic (2009) Sektorový operačný program Priemysel a Služby (Sectoral Operational Program Industry and Services). Bratislava, $112 \mathrm{p}$. 